\title{
Getting Sprouts from Mulberry Trees in invitro conditions
}

\author{
Yo. Ya. Mirzaeva ${ }^{1}$, N. A. Khujamshukurov ${ }^{2 *}$ and D. X. Kuchkarova ${ }^{3}$ \\ ${ }^{1} T S A U,{ }^{2} T C T I,{ }^{3} T A C I$ (Uzbekistan) \\ *Corresponding author
}

\section{Keywords \\ Mulberry (Morus sp.), Micro propagation, in vitro screening, M.bombycis Koidz, M..multicaulis Perr., M. nigra L., M.alba $\mathrm{L}$}

\section{Article Info}

Accepted: 28 March 2020 Available Online: 10 April 2020

\section{A B S T R A C T}

This article describes, which is widely used in the production of mulberry trees in Uzbekistan the hybrid of Uzbek mulberry (Oshima $\mathrm{I}_{2} \mathrm{~N}_{2}$ (Morus bombycis Koidz.) $\times$ SANIISH-25 (Morus multicaulis Perr.), obtained by selection Jarariq 9 variety, grafted from Balkhi (Morus alba L.) and Shotut (Morus nigra L.) trees in vitro conditions in standard nutrient medium (MS, DKW, WPM)to get explant and their developing possibilities were analyzed. As a result of the research, the average values $(R=0.05)$ of each mulberry explants were compared to the total samples in standard nutrient medium.In particular, in MS (standard) primary nutrient medium, the average budding time of the explant was 7.8 days (WPM-8.1; DKW-7.8), and the budblossoming of the explant was $46.30 \%$ (WPM-59.08; DKW-67, 73), the length of the central point of the buds, $2.92 \mathrm{~mm}$ (WPM-1.69; DKW-1.82), the length of the lower growing explant, $0.96 \mathrm{~mm}$ (WPM-1.84; DKW-1.33), the lower growing buds were observed 4.99 grains (WPM-3.5; DKW-5.05) and the overall viability of bud was $64.93 \%$ (WPM-63.17; DKW-72.74). During the observations, it was noted that the budding time of the explants vary than the blossoming of the bud. In particular, in the hybrid explant of Uzbekistan the length of the central growth point of bud was defined $2.9 \mathrm{~mm}$, which budding time 8,33 hours and in the explant of Jarariq 9 variety $3.37 \mathrm{~mm}$. Also, an average budding time were 7.88 hours, it was observed that the length of the central point of the bud was on average $1.58 \mathrm{~mm}$ in the Shotut (Morus nigra L.). The buddingtime of mulberry explants does not affect its central growth point length. According to the results of the analysis, to get explants of Uzbekistan hybrid and Jarariq 9 varieties and for developing them it is defined to effectively use MS, DKW, WPM standard nutrient medium. For Balkhi (Morus alba L.) and Shotut (Morus nigra L.) varieties, it is noted that the composition modify of MS, DKW, WPM standard nutrient medium.

\section{Introduction}

In the conditions of the Republic of Uzbekistan the mulberry tree is the only feed base of the sericulture industry, one of the strategic sources of providing the population with nutritious, rich in vitamins and medicinal properties. Mulberry trees, like other 
defensive trees evaporategroundwater from their stems, also help to improve ameliorative condition of soils by lowering groundwater levels.The importance of mulberry trees against salinization and swamping. In addition, mulberry trees have been widely used as ornamental trees in urban and rural landscaping.Therefore, the Government of the Republic of Uzbekistan has developed a program for intensively development of mulberry farming mulberry trees are planted, 25720 ha in 2017,32150 ha in 2018,39545 ha in 2019 and it has been planned mulberry fields to plant 48244 ha in 2020, 54034 ha in 2021(1). In recent years, in Uzbekistan condition the demand is growing for Shotut (Morus nigra L.) and Balkhi (Morus alba L.) mulberries in the processing and storage of agricultural products. It is known that the founder of Eastern medicine, Abu Ali Ibn Sina, in his book "Laws of Medicine" described the healing properties of Balkhi (Morus alba L.) mulberry and Morus nigra (Shotut), their fruit is a very healing drug in the treatment of high blood pressure (2). Shotut (Morus nigra L.) fruit is rich in sugars, dye and pectin, carbohydrates, mineral salts, glucose, sucrose, fructose, apple, citric, phosphoric acids, as well as iron. In Uzbekistan condition dried fruit of the mulberry is stored for a long time, mulberry fruit is widely used in industry for the preparation of various confectionery products, juices, jams, vitamins and medicines. Wine made from Shotut (Morus nigra L.) fruit has a unique pleasant aroma and is highly valued by degustators compared to wine made from apples and plums.

In Uzbekistan, by propagating Shotut (Morus nigra L.) and Balkhi (Morus alba L.) mulberry are created large plantations, mainly by getting cuttings from existing trees in residential areas and farms, and selecting grafts adapted to specific soil conditions. In Uzbekistan, the grafting time of Shotut
(Morus nigra L.) and Balkhi (Morus alba L.) mulberry is different, depending on climatic conditions and seasonal changes in Tashkent, Syrdarya, Samarkand, Jizzakh, Fergana, Andijan, Namangan and Navoi regions in early April, Kashkadarya, Surkhandarya and Bukhara regions (southern regions) in March, in the Autonomous Republic of Karakalpakstan and Khorezm region (Northern regions) in the middle of April, it is grafted from the beginning the movement of liquid in the stem of mulberry.In Uzbekistan condition, Balkhi (Morus alba L.) mulberry is propagated by vegetative waydue the seeds of fruits are not formed and are hollow. When arranging mulberry orchards, first Shotut (Morus nigra L.) and Balkhi (Morus alba L.) mulberry cuttings are prepared. Cuttings are prepared from annual branches of Shotut (Morus nigra L.) and Balkhi (Morus alba L.) mulberry in autumn, winter and early spring (before the onset of liquid movement in the tree). For grafting, annual mature sprouts of the plant are cut to a length of $40-50 \mathrm{~cm}$, binded in 50-100 pieces and stored in special rooms at a temperature of $4^{\circ} \mathrm{C}$, relative humidity of $70-80 \%$ (3).

It is known that the microclonal development method is primarily applied to plants that are very difficult to develop in other methods. This method allows you to grow in a short time, in large quantities, disease-free plant seedlings. In practice, almost all plants, decorative and room flowers, decorative shrubs and trees, fruit and vegetable crops, potatoes, fruit trees, and many medicinal plants are grown through microclonal development (4 - 8).

Although in Uzbekistan, large-scale cultivation of decorativeflowers, fruit trees (9), vines (10), potatoes (11) by microclonal development has been established, no practical research has been conducted on mulberry trees. 


\section{The purpose of the work}

Obtaining seedlings from mulberry trees and determining the importance of standard nutrient medium during their initial development.

\section{Materials and Methods}

Research methods (including equipment), Research methods (including equipment).

\section{Objects of research}

Jarariq-9, Balkhi (Morus alba L.), Shotut (Morus nigra L.) and Uzbek hybrids of mulberrywere spread, which are widely used in Uzbekistan.

The agronomic characteristics of Shotut (Morus nigra L.) are described as follows: high, i.e. the vigintidiaploid has $2 \mathrm{n}=22 \mathrm{x}=$ 308 chromosomes, and a plant equal to Shotut (Morus nigra L.) in terms of the sum of chromosomes is not found in the world. The beginning of the development period is middlelate. The deciduous trees are spherical, short, the diameter of the branch is large (thick.) The branch is large (thick) weakly clasped, dark brown, very large, longer, light brown, covered with bumps. The distance of joint is $4.0 \mathrm{~cm}$. Varieties differ from varieties by slow growth. Sprout-oblong-round, very large, size $8.5 \times 5.5 \mathrm{~mm}$, dark brown, almost black.

Characteristic features are the stickiness of the bud and the absence of side buds. It is large bud among Central Asian varieties. Bisexual, single, mostly female. Fruit - broad oval, black, very short, thick, hard to cut fruit. The average weight of 1000 seeds is $2560 \mathrm{mg}$ on average. Some seeds grow, but require $30^{\circ} \mathrm{C}$ heat and 80-90 days (late growing) for growing. Freshly harvested seeds grow in $42-$ 45 days. The leaves are broadly heart-shaped, whole or indented, glossy (light), roughedged, with thick hairs on the underside, which give it a greenish-gray.

The leaves are thick, brittle (breaks quickly). The tubes are narrowly deep, sometimes intertwined. The edge is large serrated, the upper teeth are thick, gradually sharpened, about $20.0 \mathrm{~mm}$ long. The average size of leaves on growing varieties of uncut trees is $14.2 \times 12.7 \mathrm{~cm}$. The stem of the leaf - shorthaired, light green. The average length of the leaf's stem is $2.7 \mathrm{~cm}$. Characteristic features the fruit is stored for a long time, sweet (sour) sour, the fruit is sweet-juicy, the seeds are large. The variety is very resistant to late evening frosts. Yields in unbroken Shotuts (Morus nigra L.) are 10-20 kg per bush, and 6.3-12.6 tons of mulberry leaves per hectare (12).

Balkhi mulberry (Morus alba L.) was created by grafting and is also known as quail among the locals (13). It is characterized agronomically as follows: mulberry of $3 \times(2 \mathrm{n}$ $=42$ ) variety with three ploids. The onset period of development is long. Cutting trees consist of dense, flexible twigs with medium branches. One of its main features is the curvature of the twig, which is conical, brownish-brown, thick at the bottom and thin at the top. The bulbs are very large and sparse, light brown, the distance of joint is 4.4 $\mathrm{cm}$ on average. The sprout is small, oval, plump, dark brown, the average size is $4.7 \times$ $4.0 \mathrm{~mm}$. Gender - bisexual, mostly females.

Fruits are round or oval, white, average size $21.8 \times 14.6 \mathrm{~mm}$, outpouring with a beak. The fruit is smooth, so the size will also vary. The fruits stem is short, average $2.7 \mathrm{~mm}$ in length. The fruit is seedless, and at the bottom there are unripe seeds. The fruits are juicy, sweet, early ripening. The structure of the fruit is soft, shedding, slightly crumbly. Less fruitful on cut trees. The leaf stem -green, slender, 
sparsely hairy, with an average length of 4.7 $\mathrm{cm}$. The variety is resistant to frost. Yields -1 bush - an average of $7.1 \mathrm{~kg}$, yielding an average of $86-90$ ts / ha.

Jarariq 9 variety was selected by breeders of the Uzbek Sericulture Research Institute in 2000 from a selection nursery-garden at the Jarariq Experimental Farm. The stem is a pruned tree that grows strong and has many branches. Annual varieties reach an average height of $242.8 \mathrm{~cm}$ at the end of the vegetation period. Branch - round, gray. The length of the joint distance is $2-2.5 \mathrm{~cm}$. The buds are large triangular, brown, with side buds. Gender - male. The leaves are large, whole, heart-shaped, elongated, the base is deeply incised, the tip of the leaf is of medium length. The leaf surface is smooth, dark green, the leaf edge is serrated, the average size is $16.3 \times 12.7 \mathrm{~cm}$ in spring and $19.4 \times 17.3 \mathrm{~cm}$ in summer. It differs from other varieties by strong growth of the shoot, the size of the leaf, dark green. The average yield of shrub mulberry is $72.71 \mathrm{~kg} / \mathrm{ha}(14)$.

Uzbek hybrid mulberry Oshima $\mathrm{I}_{2} \mathrm{~N}_{2}$ (Morus bombycis Koidz.) $\times$ SANIISH-25 (Morus multicaulis Perr.) was created at the Jarariq Experimental Farm of the Uzbek Sericulture Research Institute. This hybrid is reminiscent of varietal mulberries with the integrity, size and appearance of the leaf, even in the periods of sprouts, seedlings and adulthood. The body is erect, strongly developed, there are many branches, the growth period is long. Branchround, long, straight-growing, vigorous, gray in color, various forms, the distance of joint average $3-5 \mathrm{~cm}$, erect.

The buds are medium-large, brown, the average side buds are $3-4 \mathrm{~mm}$ in size. The leaves are wholly, large, ovate-oblong, medium-thick, medium-veined, the surface is rough, the average size of a summer leaf is $22.4 \times 16.1 \mathrm{~cm}$. The average weight of a summer leaf is $6.86 \mathrm{~g}$. Gender - female. Fruit - cylindrical, dark black, fruitful, seeds are dark. Mulberry seeds are grown on the farms of Uzbekistan from the parental varieties of this hybrid mulberry. The yield is $1.825 \mathrm{~kg}$ per 1 bush of mulberry bush and $91.25 \mathrm{~kg} / \mathrm{ha}$ per 1 ha (15).

Timerosal 0.0005-0.001 mg / 1, hypochlorite (Na or Ca salt) $1-10 \%$ solution, Silver nitrate (AgNO3) 0.001-0.005\% and ethyl alcohol 70A $96 \%$ solution was used as a sterilizer. The following nutrients were used for in vitro culture: Murasige and Skug (MS) (16), Woody plant medium (WPM) (17), DKWDriver and Kuniyuki (17). The thermolabile substances were filtered through a Millipor filter in a SWIN device. Growing conditions: photo period - $16 / 8$ hours day and night, light level 4000-6000 lux, $24-26^{\circ} \mathrm{C}$.

Relative humidity $60-70 \%$. The process of introduction of mulberry into in vitro culture was carried out in different nutrient compositions, and this process was carried out in several variants. The calculation of statistical error, mean, reliability intervals and standard deviations to the experimental data was performed using the computer program STATISTICA 6.0 and standard methods. The statistical significance of the results was determined using the Student t-criterion.

\section{Results and Discussion}

During the researchwas studiedthe development of mulberry tree seedlings in a wide variety of nutrient medium, where plants are widely used in vitro. The results of the research determined that in the MS nutrient medium, which is widely used in scientific research, the average budding time of Uzbek hybrids was 6.6 days, Jarariq 9 and 8.33 Balkhi (Morus albaL) mulberry - 8.6 and Shotut (Morus nigra L.) 7.88 days (Table 1). In the comparative analysis, it was noted that 
the buddingtime of explant of hybrid plantations of Uzbekistan, 2 days earlier than Jarariq 9 and Balkhi (Morus alba L.) mulberry plantations, one day earlier than Shotut (Morus nigra L.). It was also observed that the rate of bud opening of the explantvaried. In particular, in the hybrids of Uzbekistan hybrid and Jarariq 9 were $51.06 \%$, $53.5 \%$, respectively, in Balkh and Shotut were 47.36 and $33.3 \%$.

During the observations, it was noted that the budding time of the explantsvaried relative to the budblossoming. In particular, in the hybrid explant of Uzbekistan the length of the central growth point was $2.9 \mathrm{~mm}$, while the budding time was 8.33 hours, it was determined $3.37 \mathrm{~mm}$ in Jarariq 9. It was also observed that the length of the central point of the bud was $1.58 \mathrm{~mm}$ on average in the Shotut (Morus nigra L.) expansion, with an average budding time of 7.88 hours. This suggests that the budding time of mulberry tree seedlings does not affect its central growth point length. The same indicators can be observed in the WPM nutrient medium (Table 2). In particular, the hybridization of Uzbekistan had a ripening time of 7.33 days, the length of the central point of the bud was $1.25 \mathrm{~mm}$, and the budding time was 7.6 days, and in the Jarariq 9 explant it was $3.59 \mathrm{~mm}$.

In the standard nutrient medium studied, a cross-correlation of the number of lowergrowing shoots of the seedlings was also observed. In particular, the average number of lower growing shoots in the hybrids of Uzbekistan in the MS medium was 5.7, while in the WPM medium it was 3.5, and in the DKW 7.6 (Table 1-3). It was also found that the budviability of Uzbekistan hybrids was $75.01 \%$ on average in the study nutrient medium, $74.75 \%$ in Jarariq 9, 60.48\% in Balkhi (Morus alba L.) and 57.54\% in Shotut (Morus nigra L.).
During the research, the development explants of mulberry tree seedlings studied in different standard nutrient medium were analyzed. The results showed that the budding time of the explants averaged 8.1 days in the WPM medium and 7.8 days in the MS and DKW medium.

Blossoming bud in the explants was observed in an average of $59.08 \%$ in the WPM nutrient medium, $46.30 \%$ in the MS nutrient medium, and an average of $67.73 \%$ in the DKW nutrient medium. When the viability of the explant buds was studied in terms of nutrient media, it was observed that DKW was $72.74 \%$ in the nutrient medium, WPM was $63.17 \%$ in the nutrient medium, and MS was $64.93 \%$ on average in the nutrient medium. However, an inverse correlation can be observed, including the fact that in the MS medium the explant buds of Uzbekistan hybrids showed a survival rate of $74.73 \%$ in the MS medium, $71.46 \%$ in the WPM medium and $78.86 \%$ in the DKW medium. In Jarariq 9 variety explants, MS was found to have a survival rate of $71.46 \%$ in the nutrient medium, $82.73 \%$ in the WPM medium, and $70.06 \%$ in the DKW medium. This situation can be explained by the fact that when obtaining explants from mulberry trees depends on their varieties and exactly how they are propagated (seeds, grafts) (18).

Conclusion of the study is as follows:

In the result of research have determined that the obtained by hybrid of mulberry tree from Uzbekistan hybrid (Oshima $\mathrm{I}_{2} \mathrm{~N}_{2}$ (Morus bombycis Koidz.) $\times$ SANIISH-25 (Morus multicaulis Perr.)) and Jarariq 9 variety, obtaining explants by in vitrocondition and their development in MS, DKW and WPM nutrient medium was found to be usable. An average survival rate of $75.01 \%$ of hybrid plantations in Uzbekistan can be achieved in the studied standard nutrient medium. 
Table.1 Developing indicators, the explants of mulberry tree in MS (standard) primary nutrient medium

\begin{tabular}{|c|c|c|c|c|c|c|c|c|}
\hline $\begin{array}{c}\text { Experiment } \\
\text { Examples }\end{array}$ & $\begin{array}{c}\text { Experiment } \\
\text { Variety }\end{array}$ & $\begin{array}{l}\text { Nutrient } \\
\text { medium }\end{array}$ & $\begin{array}{c}\text { Average } \\
\text { budding time } \\
\text { of explant, } \\
\text { Day }\end{array}$ & $\begin{array}{l}\text { Blossoming } \\
\text { of bud in the } \\
\text { explant, } \%\end{array}$ & $\begin{array}{l}\text { The lengths of } \\
\text { central point of } \\
\text { buds, } \mathrm{mm}\end{array}$ & $\begin{array}{c}\text { The } \\
\text { lengths of } \\
\text { lower } \\
\text { growing } \\
\text { buds, } \mathrm{mm}\end{array}$ & $\begin{array}{c}\text { The } \\
\text { number of } \\
\text { lower } \\
\text { growing } \\
\text { buds, piece }\end{array}$ & $\begin{array}{c}\text { Viability of } \\
\text { common buds, } \\
\%\end{array}$ \\
\hline 1 & \multirow{3}{*}{$\begin{array}{c}\text { Uzbekistan } \\
\text { hybrid }\end{array}$} & \multirow[t]{3}{*}{ MS } & 6 & 35,6 & $2,81 \pm 0,88$ & $0,7 \pm 0,13$ & $3,7 \pm 0,14$ & $61,4 \pm 3,41$ \\
\hline 2 & & & 7 & 42,4 & $2,72 \pm 0,74$ & $0,9 \pm 0,08$ & $5,2 \pm 0,45$ & $74,2 \pm 0,95$ \\
\hline 3 & & & 7 & 75,2 & $3,36 \pm 0,36$ & $1,3 \pm 0,18$ & $8,2 \pm 0,19$ & $88,6 \pm 1,24$ \\
\hline \multicolumn{3}{|c|}{ Average indicator per examples } & 6,6 & 51,06 & 2.96 & 0,96 & 5,7 & $\mathbf{7 4 , 7 3}$ \\
\hline 1 & \multirow{3}{*}{$\begin{array}{l}\text { Jarariq } 9 \\
\text { variety }\end{array}$} & \multirow[t]{3}{*}{ MS } & 8 & 53,6 & $3,01 \pm 0,18$ & $0,66 \pm 0,46$ & $4,8 \pm 0,25$ & $68,8 \pm 0,31$ \\
\hline 2 & & & 8 & 54,1 & $3,24 \pm 0,11$ & $0,92 \pm 0,32$ & $5,1 \pm 0,11$ & $72,2 \pm 0,11$ \\
\hline 3 & & & 9 & 52,8 & $3,86 \pm 0,42$ & $0,82 \pm 1,14$ & $5,8 \pm 0,25$ & $73,4 \pm 1,23$ \\
\hline \multicolumn{3}{|c|}{ Average indicator per examples } & 8,33 & 53,5 & 3,37 & 0,8 & 5,23 & 71,46 \\
\hline 1 & \multirow{3}{*}{$\begin{array}{c}\text { Balkhi } \\
\text { (Morus alba } \\
\text { L.) }\end{array}$} & \multirow[t]{3}{*}{ MS } & 9 & 35,3 & $2,11 \pm 1,28$ & $1,4 \pm 0,85$ & $4,6 \pm 1,34$ & $57,6 \pm 1,41$ \\
\hline 2 & & & 8 & 48,2 & $3,24 \pm 1,14$ & $0,9 \pm 1,27$ & $5,3 \pm 0,27$ & $63,7 \pm 1,28$ \\
\hline 3 & & & 9 & 58,6 & $6,01 \pm 0,32$ & $2,4 \pm 1,44$ & $5,7 \pm 1,23$ & $78,6 \pm 0,33$ \\
\hline \multicolumn{3}{|c|}{ Average indicator per examples } & 8,6 & 47,36 & 3,78 & 1,56 & 5,2 & 66,63 \\
\hline 1 & \multirow{3}{*}{$\begin{array}{c}\text { Shotut } \\
\text { (Morusnigra } \\
\text { L.) }\end{array}$} & \multirow[t]{3}{*}{ MS } & 8 & 28,3 & $1,21 \pm 0,18$ & $0,4 \pm 0,23$ & $2,1 \pm 0,24$ & $33,4 \pm 1,12$ \\
\hline 2 & & & 7 & 28,3 & $1,41 \pm 0,21$ & $0,3 \pm 0,11$ & $4,1 \pm 0,11$ & $39,1 \pm 0,88$ \\
\hline 3 & & & 9 & 43,3 & $2,13 \pm 0,11$ & $0,9 \pm 0,22$ & $5,3 \pm 0,13$ & $68,2 \pm 1,44$ \\
\hline \multicolumn{3}{|c|}{ Average indicator per examples } & 8,0 & 33,3 & 1,58 & $\mathbf{0 , 5 3}$ & 3,83 & 46,9 \\
\hline \multicolumn{3}{|c|}{$\begin{array}{l}\text { A verage indicator according to } \\
\text { common examples, } P=0,05\end{array}$} & 7,8 & 46,30 & 2,92 & 0,96 & 4,99 & 64,93 \\
\hline
\end{tabular}


Table.2 Developing indicators, the explants of mulberry tree in WPM (standard) primary nutrient medium

\begin{tabular}{|c|c|c|c|c|c|c|c|c|}
\hline $\begin{array}{c}\text { Experiment } \\
\text { examples }\end{array}$ & $\begin{array}{c}\text { Experiment } \\
\text { Variety }\end{array}$ & $\begin{array}{l}\text { Nutrient } \\
\text { medium }\end{array}$ & $\begin{array}{c}\text { Average } \\
\text { budding time of } \\
\text { explant, } \\
\text { Day }\end{array}$ & $\begin{array}{l}\text { Blossoming of } \\
\text { bud in the } \\
\text { explant, \% }\end{array}$ & $\begin{array}{l}\text { The lengths of } \\
\text { central point of } \\
\text { buds, } \mathrm{mm}\end{array}$ & $\begin{array}{l}\text { The lengths } \\
\text { of lower } \\
\text { growing } \\
\text { buds, } \mathbf{m m}\end{array}$ & $\begin{array}{c}\text { The } \\
\text { number of } \\
\text { lower } \\
\text { growing } \\
\text { buds, piece }\end{array}$ & $\begin{array}{c}\text { Viability of } \\
\text { common buds, } \\
\%\end{array}$ \\
\hline 1 & \multirow{3}{*}{$\begin{array}{c}\text { Uzbekistan } \\
\text { Hybrid }\end{array}$} & \multirow[t]{3}{*}{ WPM } & 7 & 52,2 & $1,12 \pm 1,21$ & $0,6 \pm 0,11$ & $2,8 \pm 0,41$ & $68,5 \pm 1,14$ \\
\hline 2 & & & 8 & 59,6 & $0,92 \pm 0,36$ & $0,9 \pm 0,28$ & $4,6 \pm 1,14$ & $77,4 \pm 1,33$ \\
\hline 3 & & & 7 & 58,8 & $1,72 \pm 0,12$ & $0,6 \pm 1,13$ & $3,1 \pm 1,23$ & $68,5 \pm 0,56$ \\
\hline \multicolumn{3}{|c|}{ Average indicator per examples } & 7,33 & 56,8 & 1,25 & 0,7 & 3,5 & 71,46 \\
\hline 1 & \multirow{3}{*}{$\begin{array}{l}\text { Jarariq } 9 \\
\text { variety }\end{array}$} & \multirow[t]{3}{*}{ WPM } & 9 & 68,6 & $3,11 \pm 0,23$ & $4,6 \pm 0,33$ & $6,6 \pm 1,11$ & $68,6 \pm 0,44$ \\
\hline 2 & & & 7 & 76,6 & $4,21 \pm 1,13$ & $5,3 \pm 0,41$ & $8,2 \pm 1,24$ & $92,8 \pm 1,22$ \\
\hline 3 & & & 7 & 83,4 & $3,46 \pm 1,33$ & $4,9 \pm 0,12$ & $7,4 \pm 0,38$ & $86,8 \pm 0,33$ \\
\hline \multicolumn{3}{|c|}{ Average indicator per examples } & 7,6 & 76,2 & 3,59 & 4,93 & 7,4 & 82,73 \\
\hline 1 & \multirow{3}{*}{$\begin{array}{c}\text { Balkhi } \\
\text { (Morus alba } \\
\text { L.) }\end{array}$} & \multirow[t]{3}{*}{ WPM } & 9 & 48,4 & $1,21 \pm 1,28$ & $1,2 \pm 0,14$ & $1,2 \pm 0,24$ & $33,2 \pm 1,41$ \\
\hline 2 & & & 9 & 56,3 & $0,93 \pm 0,11$ & $0,9 \pm 0,11$ & $2,3 \pm 1,14$ & $38,3 \pm 1,28$ \\
\hline 3 & & & 8 & 61,2 & $1,34 \pm 0,42$ & $1,4 \pm 0,32$ & $1,6 \pm 0,33$ & $48,2 \pm 0,33$ \\
\hline \multicolumn{3}{|c|}{ Average indicator per examples } & 8,66 & 55,3 & 1,16 & 1,16 & 1,7 & 39,9 \\
\hline 1 & \multirow{3}{*}{$\begin{array}{c}\text { Shotut } \\
\text { (Morusnigra } \\
\text { L.) }\end{array}$} & \multirow[t]{3}{*}{ WPM } & 9 & 43,3 & $0,48 \pm 1,42$ & $0,46 \pm 0,12$ & $1,2 \pm 1,33$ & $45,5 \pm 0,11$ \\
\hline 2 & & & 9 & 52,2 & $0,96 \pm 1,24$ & $0,62 \pm 0,42$ & $1,8 \pm 1,14$ & $68,1 \pm 0,42$ \\
\hline 3 & & & 9 & 48,6 & $0,86 \pm 1,32$ & $0,72 \pm 0,33$ & $1,2 \pm 0,36$ & $62,2 \pm 0,34$ \\
\hline \multicolumn{3}{|c|}{ Average indicator per examples } & 9 & 48,03 & $\mathbf{0 , 7 6}$ & 0,6 & 1,4 & 58,6 \\
\hline \multicolumn{3}{|c|}{$\begin{array}{l}\text { Average indicator according to } \\
\text { common examples, } P=0,05\end{array}$} & 8,1 & 59,08 & 1,69 & 1,84 & 3,5 & 63,17 \\
\hline
\end{tabular}


Table.3 Developing indicators, the explants of mulberry tree in DKW (standard) primary nutrient medium

\begin{tabular}{|c|c|c|c|c|c|c|c|c|}
\hline $\begin{array}{c}\text { Experiment } \\
\text { examples }\end{array}$ & $\begin{array}{l}\text { Experiment } \\
\text { Variety }\end{array}$ & $\begin{array}{l}\text { Nutrient } \\
\text { medium }\end{array}$ & $\begin{array}{c}\text { Average } \\
\text { budding time of } \\
\text { explant, } \\
\text { Day }\end{array}$ & $\begin{array}{l}\text { Blossoming of } \\
\text { bud in the } \\
\text { explant, \% }\end{array}$ & $\begin{array}{l}\text { The lengths of } \\
\text { central point of } \\
\text { buds, } \mathrm{mm}\end{array}$ & $\begin{array}{l}\text { The lengths } \\
\text { of lower } \\
\text { growing } \\
\text { buds, } \mathbf{m m}\end{array}$ & $\begin{array}{c}\text { The } \\
\text { number of } \\
\text { lower } \\
\text { growing } \\
\text { buds, piece }\end{array}$ & $\begin{array}{c}\text { Viability of } \\
\text { common buds, } \\
\%\end{array}$ \\
\hline 1 & \multirow{3}{*}{$\begin{array}{c}\text { Uzbekistan } \\
\text { hybrid }\end{array}$} & \multirow[t]{3}{*}{ DKW } & 8 & 68,4 & $3,12 \pm 1,18$ & $1,8 \pm 0,32$ & $6,6 \pm 0,38$ & $72,6 \pm 0,44$ \\
\hline 2 & & & 7 & 72,2 & $2,48 \pm 1,36$ & $2,6 \pm 0,42$ & $7,4 \pm 0,64$ & $77,4 \pm 0,12$ \\
\hline 3 & & & 8 & 78,8 & $2,24 \pm 1,32$ & $3,4 \pm 0,13$ & $8,8 \pm 0,44$ & $86,6 \pm 0,42$ \\
\hline \multicolumn{3}{|c|}{ Average indicator per examples } & 7,6 & 73,13 & 2,61 & 2,6 & 7,6 & 78,86 \\
\hline 1 & \multirow{3}{*}{$\begin{array}{c}\text { Jarariq } 9 \\
\text { variety }\end{array}$} & \multirow[t]{3}{*}{ DKW } & 8 & 78,4 & $2,14 \pm 0,11$ & $0,8 \pm 0,42$ & $6,4 \pm 0,11$ & $69,4 \pm 1,11$ \\
\hline 2 & & & 8 & 72,4 & $1,66 \pm 0,33$ & $1,2 \pm 0,11$ & $5,2 \pm 0,33$ & $72,2 \pm 0,18$ \\
\hline 3 & & & 8 & 78,6 & $2,28 \pm 0,24$ & $1,1 \pm 0,24$ & $6,2 \pm 1,12$ & $68,6 \pm 1,14$ \\
\hline \multicolumn{3}{|c|}{ Average indicator per examples } & 8 & 76,4 & 2,02 & $\mathbf{1 , 0 3}$ & 5,93 & 70,06 \\
\hline 1 & \multirow{3}{*}{$\begin{array}{c}\text { Balkhi } \\
\text { (Morus alba } \\
\text { L.) }\end{array}$} & \multirow[t]{3}{*}{ DKW } & 8 & 68,2 & $1,4 \pm 1,14$ & $1,1 \pm 1,22$ & $4,6 \pm 1,01$ & $78,4 \pm 0,34$ \\
\hline 2 & & & 8 & 66,4 & $1,6 \pm 1,12$ & $0,9 \pm 1,04$ & $3,8 \pm 0,96$ & $72,2 \pm 0,28$ \\
\hline 3 & & & 8 & 62,6 & $1,1 \pm 1,33$ & $0,8 \pm 1,23$ & $3,2 \pm 0,48$ & $74,2 \pm 1,12$ \\
\hline \multicolumn{3}{|c|}{ Average indicator per examples } & 8 & 65,73 & 1,36 & $\mathbf{0 , 9 3}$ & $\mathbf{3 , 8 6}$ & 74,93 \\
\hline 1 & \multirow{3}{*}{$\begin{array}{c}\text { Shotut } \\
\text { (Morus nigra } \\
\text { L.) }\end{array}$} & \multirow[t]{3}{*}{ DKW } & 8 & 58,2 & $1,38 \pm 0,14$ & $0,86 \pm 0,22$ & $2,6 \pm 0,31$ & $68,4 \pm 1,24$ \\
\hline 2 & & & 7 & 54,6 & $1,22 \pm 0,11$ & $0,72 \pm 0,18$ & $3,1 \pm 0,44$ & $66,2 \pm 1,33$ \\
\hline 3 & & & 8 & 54,2 & $1,34 \pm 0,42$ & $0,78 \pm 0,11$ & $2,8 \pm 0,25$ & $66,8 \pm 0,86$ \\
\hline \multicolumn{3}{|c|}{ Average indicator per examples } & 7,6 & 55,66 & 1,31 & $\mathbf{0 , 7 8}$ & 2,83 & 67,13 \\
\hline \multicolumn{3}{|c|}{$\begin{array}{l}\text { Average indicator according to } \\
\text { common examples, } P=0,05\end{array}$} & 7,8 & 67,73 & 1,82 & 1,33 & 5,05 & 72,74 \\
\hline
\end{tabular}


In Jarariq 9 variety explants, the indicator is $74.75 \%$. It was found that in these nutrient medium it is possible to provide survival on average $60.48 \%$ in Balkhi (Morus alba L.) mulberry plantations and $57.54 \%$ in Shotut (Morus nigra L.) plantations.

In standard nutrient medium (MS, DKW, WPM) in the explants of Uzbekistan hybrids were 5.6 piece in low-growing buds, while in the explants of Jarariq 9 variety this indicator was 6.1 piece. In this standard nutrient medium, the average number of lowergrowing buds of Morus alba L.(Balkhi) mulberry explants was 3.5, and in the Morus alba L. (Shotut) explants was 2.6 piece. Therefore, it was determined that in obtaining mulberry explants to achieve $100 \%$ results should be modified the composition of nutrient medium (MS, DKW, WPM).

\section{Acknowledgements}

We express our gratitude to the staffs which helped us in research works the Scientific Research Institute named after O.Sodikov of the Academy of Sciences of the Republic of Uzbekistan (E.G.Khalmuratov, G.B.Nasirova) and the Tashkent Institute of Chemical Technology, Scientific Laboratory "Biotechnology" (Prof. N.A.Khujamshukurov).

\section{References}

1.Aliev X.A., Mukailov M.D. Subtropical fruits are a valuable raw material for the production of functional foods. Overview. Subtropical and ornamental gardening Review. Subtropical and decorative gardening 2017, 61, 9-15.

2.Abu Ali ibn Sino.Law of Medical Science Volume I-X Tashkent, 1996.

3.Mirzaeva Yo.Ya., Rakhmonberdiev V.K., Khaydaraliev J.R. Study of the survival rate of one- two-eyed mulberry cuttings. Materials of the scientific, technical, agricultural conference "Youth, Science, Life of the XXI Century". Oryol, Russia. 2019. p.238-245.

4.Besedina E.N., Buntsevich L.L. // Politematic networking electronic scientific journal of the Kuban State Agrarian University (Scientific journal KubSAU). -Krasnodar: KubSAU, 2015. - №07 (111).

5.Aghaye RNM, Yadollahi A, Moeini A and Sepahvand S. 2013. In vitro Culture of Gisela 6, semi-dwarf rootstock. Journal of Biodiversity and Environmental Sciences 7(20): 57-64.

6.Akhtar G, Jaskani MJ, Sajjad Y, Akram A (2016). Effect of antioxidants, amino acids and plant growth regulators onin vitropropagation of Rosa centifolia. Iranian Journal of Biotechnology 14:e1152.

7.Buntsevich L.L. Improving the production system of high-quality nonvirusplanting material for fruit and berry crops/in the book: Developments that forming of the modern shapegardening: monograph / L.L. Buntsevich, M.A. Kostyuk, E.N. Paletskaya (Besedina). - Krasnodar: GNU SKZNIISiV. - 2011. - p. 254275

8.Monticelli S, Gentile A, Frattarelli A, Caboni E (2017). Effects of the natural cytokinin meta-Topolin on in vitro shoot proliferation and acclimatization of Prunusspp. Acta Horticulture 1155:375-380.

9.Saimnazarov Y.B., Abduramanova S.Kh. In vitro multiplication of cherry rootstock Krymsk®5 (VSL-2) in vitro. IJIRMF. Volume 5, Issue-1, 2019. p.77-81.

10.Sultonov K.S. Improvement of methods for receiving high quality grape saplings by in vitro method. // International Research Journal of 
Agricultural Sience and soil Science (IRJAS). International Research Journals, 2017. - Vol. 7(1). - P. 008011.

11.Xalmuratov E.G., Nasyrova G.B., Sabirova N.Sh. Satyvaldieva N., Edilova G.E. Controlled reversible inhibition of the process of growth of microclub potatoes, obtained in vitro. Republican scientific conference "Modern problems of genetics, genomics and biotechnology", Tashkent, May 18, 2018. p.254.Абдуллаев У. Тутчилик. Т.: Мехнат, 1991 й. 99-100 б.

12.M.I.Gerbinskaya., A.Pulatov. The main methods of vegetative propagation of the mulberry. T.: Fan, 1975. p.45-47.

13.Abdullaev U. Sericulture. T.: Mehnat, 1991. p.99-100.

14.Muhammad Akram. Faheem Aftab. Department of Botany, University of the Punjab, Lahore-54590, Pakistan Corresponding author: faheem. botany@.pu.edu.pk Pak. J. Bot., 44: 285-289, Special Issue March 2012.
Efficient micropropagation and rooting of king white mulberry (Morus macrouramiq.) varlaevigata from nodal explants of mature tree.

15.Kochkarov O', Umarov Sh., Kholmatov D., Juraev M. Varieties, forms and hybrids of mulberry varieties in the world created in Uzbekistan, Volume 2, T .: Fan, 2012. p.87-88.

16.Murashige T., Skoog F. A revised medium for rapid growth and bio assays with tobacco tissue cultures // Physiologia Plantarum.-1962.-V.15.p.473-497.

17.Driver. J Ways of artificial tissue growth in the laboratory. // Acad. M.Mirzaev nom. BUva V ITI. Tashkent: 2016. p.12-14.

18.Tanmoy Sarkar., Thallapally Mogili., Vankadara Sivaprasad. Improvement of abiotic stress adaptive traits in mulberry (Morus spp.): an update on biotechnological interventions. Biotech (2017) 7:214.

\section{How to cite this article:}

Mirzaeva, Yo. Ya., N. A. Khujamshukurov and Kuchkarova, D. X. 2020. Getting Sprouts from Mulberry Trees in invitro conditions. Int.J.Curr.Microbiol.App.Sci. 9(04): 3152-3161. doi: https://doi.org/10.20546/ijcmas.2020.904.367 